\title{
DENOMINAL VERBS IN TOBA BATAK LANGUAGE
}

\author{
Esron Ambarita \\ Faculty of Letters \\ University of Methodist Indonesia \\ esronambarita@gmail.com
}

\begin{abstract}
The central issue in this research is denominal verbs in Toba Batak language that is the formations of verbs from nominal bases through affixations and through lexical form. The morphological process occured in this kind of formation is derivational because it brings about new different word class from its base. In other words, derivational process produces different lexical identity and therefore, it has different lexical meaning. In Toba Batak language denominal verbs can be classified into nine categories, they are: (1) base-zero category, (2) base-hon category, (3) base-i category, (4) mar-base category, (5) mampar-base-hon category, (6) tar-base category, (7) tarbase-i category, (8) hona-base category, and (9) marsi-base-an category. In Toba Batak language it was found that the form of the nominal base and the form of the verb produced is the same in base-zero category. Therefore, the word class of the word will be known as noun or verb from sentence valency or from the context of the sentence where the words are used. For category (8) hona-base category, "hona" which means "suffer from" is a lexical form attached to bases to form new words as verbs. This category is very different from others in which other categories use affixes instead of lexical form. The new word formed can be transitive or it can be intransitive depends on the affixes attached.
\end{abstract}

Key words: denominal verbs, derivational process, nouns, verbs

\section{INTRODUCTION}

The central issue in this research is denominal verbs in Toba Batak language that is the formations of verbs from nominal bases through affixations. In Toba Batak language, for instance, the word abit 'clothes' + prefix mar- -> marabit 'get dressed'. The process occurs in the word formation is derivational because the word classes are different. Abit is a noun and marabit is a verb. On the other hand, inflectionally, a new word is formed form a base without changing its word class. For example, the word hundul 'sit' as a verb + suffix - hon -> hundulhon 'to ask someone to sit' is also a verb.

A research that has something to do with this research was done by Subroto (1985) in his dissertation in bahasa Indonesia on Transposisi dari Adjectiva menjadi 
verba dan Sebaliknya dalam Bahasa Jawa. The research discusses word formation in bahasa Indonesia derivationally and inflectionally.

The development of this theory inspires the writer to apply it in Toba Batak language. This research is limited to the formation of verbs from nominal bases in relation to the affixation productivity and lexical item.

\section{REVIEW OF LITERATURE}

Morphologically, word formation can be done derivationally and inflectionally. A lot of linguists have discussed these issues. However, most linguists agree that the essence of word formation is the formation which produces new word or new lexeme (Merchand, 1969: 3). Word is minimal form that can be used as a base to form new word (Aronoff, 1976: 39); his theory is known as The Word Based Hypothesis. The new word formed can be the result of inflectional process or derivational process. In other words, there is a special segment to trace that kind of new word class formation called derivational morphology, instead of infectional morphology.

For example, in Toba Batak language, goar (noun) 'name' -> manggoari (active verb) 'say name' -> digoari (passive verb) 'named'. Bound morpheme mang- and $-i$ in the word manggoari and bound morpheme $d i$ - and $-i$ in the word digoari are called derivational morphemes because their presence to those words change the word class of the nominal base goar from noun to verbs (Fromkin and Hyams. (2007: 84). Besides, the meaning also differs from goar name as noun to manggoaari 'say name' as verb and digoari 'named' as verb as well.

The same opinions are also stated by Katamba (1994: 47) in his book Morphology, who distinguishes affixes in two types, they are derivational affixes and inflectional affixes. Furthermore, , Katamba (1994: 50) proposes three arguments for derivational affixes, they are:

(1) derivational affixes change the lexical meaning of the new word although the word class in not changed. In Toba Batak language, for example, the word ajar (noun) 'advice' -> pangajar (noun) 'teacher'. From the two examples in Toba Batak language above, we can see that that the word class of ajar and pangajar is the same, they are nouns. However, the lexical meaning of 
the two words is different. Ajar has semantic distinctive features like non alive, non human, whereas pangajar is alive and human.

2. the formation of the word will result in new word class. In Toba Batak language, for example, if the word dalan (noun) 'way' is added with prefix mar- it will be mardalan (verb) 'walk'. It can be seen that dalan as noun is changed to mardalan as verb. In this context, the change does not only occur to the word class but also to the lexical meaning of the new word.

3. change sub word class of words such as book (noun) $\rightarrow \quad$ booklet (noun). The writer did not find any result for this formation in Toba Batak language.

Based on the explanation above, it can be seen that words, morphologically, can be processed to form new word through affixes as morphemes. Talking about morphemes, inflection is the change of words as morphemes which does not change the identity of lexical word, whereas derivation is the change of morphemes which result in new lexeme (Verhaar, 1996: 144). Both derivational and inflectional produce morphemic change. Morphemic change is meant to say the change of word form sincronically because of affixation. On the other hand, derivation changes lexical identity. The change of the lexical identity can be shown by the elaboration of semantic features of the word.

A lot of linguists have argued to distinguish between inflectional morphology and derivational morphology such as Nida (1949), Lyons (1968), Matthews (1974), Bauer (1983), Aronoff and Fudeman (2005), Fromkin (2007) and Stump (2001). However, as far as the writer concern, the proposal on inflection and derivation argued by Nida (1949) are summarized as in the following:

1. inflectional rules never change word class, whereas derivational rules has probability to change word class.

2. derivational formation has external distribution similar to simple word, whereas inflectional formation has internal ditribution.

3. statistically derivational formation has more variations than inflectional formation.

4. the distribution of derivational affixes is very limited, whereas the distribution of inflectional affixes is widely done. 
5. derivational rules changes the meaning of the lexical base, whereas inflectional rules only changes grammatical meaning.

6. derivational rules are nucleus, while inflectional rules are pheripheral

7. derivational rules are not completely productive, whereas inflectional rules are productive.

8. inflectional rules has regular grammatical meaning, however, derivational rules has semantic idiosyncraises.

9. inflectional rules can be predicted because of the speakers' intuition, whereas derivational rules cannot be predicted although by using the speakers' intuition.

From the explanation above it can be said that derivational word formation produces new lexeme of which the word class is different such as the word goar (noun) 'name' -> goari (noun) 'say name'. On the other hand, inflectional word formation produces different new lexemes from the same lexeme. In Toba Batak language, for example, the words pangajar (noun) 'teacher', parsiajaran (noun) 'lesson' pangajaran (noun) 'the way of teaching' are different words from lexeme AJAR (noun) 'advice'.

In other words, the product of affixation and lexeme derivationally is another manifestation of word formation to form new different word not only new different word class but also new different lexical meaning. This argument is supported by Lyons (1968: 197) in his book Introduction to Theoretical Linguistics. He states that lexeme is an abstract union of abstaction product from different form in inflectional paradigm because of certain syntactical rules.

For example, as already mentioned above, the word pangajar (noun), parsiajaran (noun), and pangajaran (noun) are different manifestations of lexeme AJAR as noun. The appearances of the words pangajar, parsiajaran' and pangajaran syntactically depend on the sentence constructions. The use of the three words in Toba Batak language can be seen in the following sentences:

1. Ise pangajar ni murid di ruang $\underline{1}$ ?

Who teacher of students in room 1 ?

'Who is the teacher of students in room 1?'

2. Maol hian parsiajaran ni SD saonari bah! Difficult very lessons of Elemantary School today EXCLAMATION! 
'The lessons of Elemenatry School students today are very difficult.'

3. Denggan hian pangajaran ni sude guru di sikkola an. Good very the way of teaching of all teachers at school that. 'The way of teaching of all teachers at that school is very good.'

A lexeme can be simple and it can be complex as well. Whatever lexeme it is, lexeme is written in uppercase like lexeme $A J A R$ above. For example, from the word parkarejoan (noun) we can derive PARKAREJO (noun) as a complex lexeme and KAREJO (noun) as simple lexeme because it consists of one morpheme.

\section{METHOD OF RESEARCH}

The study was done by using qualitative design. It is a kind of research to investigate the formation of verbs from nominal bases in Toba Batak language. The data of this research are limited to words in Toba Batak language that consist of affixations especially verbs which are supposed to derive from nouns. Therefore, the data taken deal with affixation processes in the formation of verbs from nominal bases in Toba Batak language.

There are three types of data in this research, they are: (1) oral, (2) written, and (3) intuition.

a. Oral data was collected by observing, interviewing, listening attentively, and chatting with the informants.

b. Written data was originated from Kamus Batak Toba Indonesia (2012), written by Warneck J., translated by P. Joosten, Leo OFMCap., from its original title Toba Bataks-Netherlands Woordenboek (1905), published by Penerbit Bina Media Perintis Medan.

c. Intuition data was based on the writer's intuition because the writer is a native Toba Batak language speaker. Speakers of a language normally posses knowledge not only about the words of the language but also about the composition and structure of the words (Halle, 1973: 1)

The techniques of data analysis is done by identifying smallest meaningful linguistic unit such as morpheme which repeats frequently with the same form. After that the correlation is found based on meaning. For instance, if the following forms are 
found: alo, aloalo, mangalo, maralo, maralohon, marsialoan, pangalo, pangaloan, and paraloan the first step to be done is to identify the morphemes of those words not only bound morpheme such as prefix, suffix, infix if any, or any other affixes, but also free morpheme.

To analyze its base and the word class of its base and also to analyze the result of the word formation there are at least three criteria to be considered, they are, (1) meaning, (2) morphological features, and (3) syntactical valency of the word under discussion.

For example, mangalo which is formed from nominal base alo is a verb. The argument is that the feature of the meaning of alo shows action. The morphological feature is that prefix ma- in mangalo can be changed to di- $\rightarrow$ dialo. Syntactically, the valency features of the verb mangalo is that the word can be preceded by time expression such as dang, naeng, pas, nunga as in dang mangalo, naeng mangalo, pas mangalo, nunga mangalo.

The data collected are various, not only in number but also in their forms. Based on the various data collected, they can be classified into certain types. Derivational word formation is irregular, that is to say that not all words of the same type and of the same word class form the same morphological features when affixes are attached.

For instance, the attachments of prefix $\left\{\mathrm{ma}^{-}\right\}$to the base sendok in manendok as verb that means 'pick something up using spoon' and to the base sakkul in manakkul as verb that means 'to hoe' do not produce the same semantic features. The same case also occurs to the attachments of suffix $\{-i\}$ to base goar $->$ goari as verb 'say name' and to base pupuk $+i \rightarrow$ 'to put fertilizer in'. Suffix $-i$ has different meaning in those two words.

\section{DISCUSSIONS}

The formation of verbs from nominal bases in Toba Batak language using affixes and lexical item is done through base category. However, word formation morphologically is not only based on noun. The formation, on the other hand, can be based on verb, adjective, adverb, or numeric. This research focuses its discussion on verb formations from nominal bases. As it has been mentioned above, word formation can be derivational and inflectional. As the title of this research proposes, it is very clear 
that this research is derivational word formation because it discusses the formation of verbs from nominal bases. In other words, it clearly shows different word class from noun to verb.

The results of the verb formations from nominal bases can be classified into nine categories, they are: (1) base-zero category, (2) base-hon category, (3) base-i category, (4) mar-base category, (5) mampar-base-hon category, (6) tar-base category, (7) tarbase- $i$ category, (8) hona-base category, and (9) marsi-base-an category.

\subsection{Denominal Verbs Using Base-Zero Category}

In Toba Batak language, denominal verbs which the writer classified as basezero category is formed from noun to verb without lexical change. However, the word class of the words are different although they look the same. That is why, a noun form is not different from a verb form. The data that belong to this category are presented in the following:

$\begin{array}{llll}\begin{array}{ll}\text { Nominal Base } \\ \text { sakkul }\end{array} & \text { Gloss } & \text { Verb Form } & \text { Gloss } \\ \text { gutting } & \text { hoe } & \text { sakkul } & \text { to hoe } \\ & \text { scissors } & \text { gutting } & \text { to cut something using } \\ & & & \text { scissors } \\ \text { parang } & \text { long and big knife } & \text { parang } & \text { to cut something using long } \\ & & & \text { and big knife } \\ \text { rassun } & \text { poison } & \text { rassun } & \text { put poison into food or drink }\end{array}$

The processes occur in sakkul as noun -> sakkul as verb, gutting as noun -> gutting as verb, and parang as noun -> parang as verb are derivational processes because the word class of the source words and the words produced are different. If the words stand alone, the word class of the words cannot be known unless they are put into sentences. In other words, the word class of the word will be known as noun or verb from sentence valency or from the context of the sentence where the words are used. For example:

1. Sakkul jolo juma ta an asa ta suan jagung.

Hoe before garden our that so that we plant corn.

'Please hoe the garden so that we plant corn there.' 
2. Mago sakkul nami daba.

Lost hoe our oh my God!

'Oh my God, we lost our hoe.'

The same form is not homonymy or polysemy. One of the form, that is, verb form is the result of morphological process from noun to verb. Whereas the other form is nominal base as the base of the verb form. There is not lexical change between the source word and the target word in this category, that is why, the writer called it basezero category. It is because the affixation process uses zero morfem. That is to say that derivational process form verbs from nouns without affixation process. After the verb is formed from nominal base, these two forms are different lexeme eventhough they look the same.

Based on the data above, we can see that nominal base sakkul 'hoe' in Toba Batak language cannot be manipulated into other form using any affix. However, the new word sakkul as verb can be formed into other word form but still the word class is verb with various paradigms as follows.

sakkul sakkuli sakkulhon manakkul manakkuli manakkulhon

Verb formations from sakkul -> sakkuli -> sakkulhon -> manakkulhon -> manakkuli -> manakkulhon are inflectional processes because the word class of those words are the same.

Based on the data above, all of the words refer to tools to do something. There are a lot of words that belong to this category in Toba Batak language. In other words, they are very productive. However, not all words that refer to tools can be formed using base-zero category. Therefore, verb formation from nominal bases using base-zero category are unpredictable. Syntactically, the verbs formed from this kind of nominal bases are transitive verbs which oblige the presence of nominal argument or nominal phrase as its complement.

\subsection{Denominal Verbs Using Base-hon Category}


Verb formation from nominal bases using base-hon category is different from verb formation from nominal bases using zero category. In zero category, for example, the formation of sakkul as noun -> sakkulhon as verb must be preceded by sakkul as verb as in the following scheme: sakkul (noun) -> sakkul (verb) -> sakkulhon (verb). In base-hon category, the nominal bases directly form verbs by attaching suffix -hon to the base as in the following:

\begin{tabular}{|c|c|c|c|}
\hline Nominal Base & Gloss & Verb Form & Gloss \\
\hline sakku & pocket & sakkuhon & to put something into the pocket \\
\hline horban & barn & horbanhon & to put (chicken) into the barn \\
\hline poda & advice & podahon & to give advice \\
\hline usaha & effort & usahahon & to make an effort \\
\hline ulos & ulos & uloshon & to put an ulos to somebody's shoulder \\
\hline salimut & blanket & salimuthon & to put blanket to somebody \\
\hline
\end{tabular}

The examples can be seen in the sentences below.

3. Sakkuhon hepeng mi, annon mago.

Pocket-suffix money your, later loose.

'Please put your money into your pocket, otherwise, you will loose it.'

4. Salimuthon ma songon $\mathrm{i}$ asa unang ngalian ho.

Hoe SUFFIX please as you like so that don't cold you.

'Please put on the blanket so that you are not cold.'

5. Horbanhon jolo manuk ta an, nga sore hian ari.

Barn SUFFIX before chicken our those, already afternoon too day.

'Please put the chicken into the barn, it's too late.'

The three sentences which consist of verbs sakkuhon, salimuthon, and horbanhon derive from nominal lexemes SAKKU, SALIMUT, and HORBAN respectively. These lexemes automatically form the verbs sakkuhon, salimuthon, and horbanhon that change the word classes. Sakku, salimut, and horban are nouns. The verbs sakkuhon further can form the following paradigms:

manakkuhon 'to put something into the pocket',

disakkuhon (passive form) 'something is put into the pocket' 
isakkuhon (passive form) 'something is put into the pocket'

tarsakkuhon

'something can be put into the pocket'

The verbs salimuthon further can form the following paradigms:

manalimuthon 'to put on blanket'

disalimuthon (passive form) 'blanket is put on'

isalimuthon (passive form) 'blanket is put on'

tarsalimuthon 'blanket can be put on'

The verbs horbanhon further can form the following paradigms:

manghorbanhon 'to put something into the barn'

dihorbanhon (passive form) 'something is put into the barn'

ihorbanhon (passive form) 'something is put into the barn'

tarhorbanhon 'something can be put into the barn'

\subsection{Denominal Verbs Using Base-i Category}

Verb formation from nominal bases using base- $i$ category is formed by attaching suffix $-i$ to the base directly as in the following:

$\begin{array}{llll}\text { Nominal Base } & \text { Gloss } & \text { Verb Form } & \text { Gloss } \\ \text { sakku } & \text { pocket } & \text { sakkui } & \text { to put something into the pocket } \\ \text { poda } & \text { advice } & \text { podai } & \text { to give advice } \\ \text { salimut } & \text { blanket } & \text { salimuti } & \text { to put blanket to somebody } \\ \text { labang } & \text { hammer } & \text { labangi } & \text { to hammer } \\ \text { goar } & \text { name } & \text { goari } & \text { to say name }\end{array}$

The examples can be seen in the sentences below.

7. Poda $i$ ja jolo bere mi, asa burju ibana.

Advice SUFFIX please before niece your, so that kind him.

'Please give advice to your niece so that he is a kind person.'

8. Ulosi ma iboto mi di pesta on asa las roha na. 
Ulos SUFFIX please sister your in party this so that hot heart her.

'Please put an ulos to your sister in this party so that she is happy.'

9. Labang $i \quad$ annon sude pakku na di tebbok ni dapur an.

Hammer SUFFIX later all nails that in wall of kitchen that.

'Later, please hammer all the nails on the wall of the kitchen.'

The formation of the verbs podai, ulosi, and labangi in the sentences above are done automatically by attaching suffix $-i$ to the nominal bases PODA, ULOS, and $L A B A N G$ as their lexemes.

The verbs podai further can form the following paradigms:

mamodai 'to give advice'

dipodai (passive form) 'advice is given'

ipodai (passive form) 'advice is given'

tarpodai 'advice can be given'

The verbs ulosi further can form the following paradigms:

mangulosi 'to put ulos onto somebody's shoulder'

diulosi (passive form) 'ulos is put onto somebody's shoulder'

iulosi (passive form) 'ulos is put onto somebody's shoulder'

tarulosi 'ulos can be put onto somebody's shoulder'

\subsection{Denominal Verbs Using mar-Base Category}

Derivational formation of nominal bases using mar-base category refers to possession or it can mean to put on something. Otherwise, it can mean 'go by ...' as mentioned by the nominal base as shown in the following examples:

$\begin{array}{llll}\text { Nominal Base } & \text { Gloss } & \text { Verb Form } & \text { Gloss } \\ \text { bunga } & \text { flower } & \text { marbunga } & \text { having flowers } \\ \text { buah } & \text { fruit } & \text { marbuah } & \text { having fruit } \\ \text { kareta } & \text { motor cycle } & \text { markareta } & \text { having a motor cycle, going by a motorcycle } \\ \text { sipatu } & \text { shoes } & \text { marsipatu } & \text { wearing shoes } \\ \text { jabu } & \text { house } & \text { marjabu } & \text { having hause } \\ \text { kumis } & \text { moustache } & \text { markumis } & \text { having moustache } \\ \text { motor } & \text { car } & \text { marmotor } & \text { having a car, going by a car }\end{array}$




$\begin{array}{llll}\text { amang } & \text { father } & \text { maramang } & \text { having father, calling father } \\ \text { inang } & \text { mother } & \text { marinang } & \text { having mother, calling mother }\end{array}$

The examples can be seen in the following sentences.

10. Nunga marbunga sabetta na di ladang, satokkin nai marbuah nama. Already PREFIX flower chilly our that in garden, later again PREFIX fruit that. 'Our chillies in the garden have flowers, they will have fruit.'

11. Boasa markareta hotor mu?

Why PREFIX motor cycle you? Exist PARTICLE car your?

'Why do you go by motor cycle? You have a car.'

The formations of verbs from nominal bases in the words above using mar-base category are shown by the attachment of prefix mar- to the nominal bases. The meaning emerges by the presence of prefix mar-vary. If the thing is something that can be put on to our body it can mean 'wearing' as in marsipatu 'wearing shoes'. If it is something that can be driven or ridden it can mean 'having' or 'riding' or 'driving' as in markareta 'having or riding motor cycle', marmotor 'having or driving a car'. This kind of intransitive verbs are very productive in Toba Batak language.

\subsection{Denominal Verbs Using mampar-Base-hon Category}

Denominal verbs in this case do not occur directly as they occur in denominal verbs in base-hon category, as in sakku (noun) 'pocket' -> sakkuhon (verb) 'to put something into the pocket', base- $i$ category, as in goar (noun) 'name' -> goari (verb) 'say name', and in mar-base category, as in bunga (noun) 'flower' -> marbunga (verb) 'having flower'

In Toba Batak language, transitive verbs using mampar-base-hon category can be seen as in the following.

Nominal Base

meam-meam

\section{Gloss}

game

\section{Verb Form}

mamparmeam-meamhon

\section{Gloss}

play game 


$\begin{array}{llll}\text { amang } & \text { father } & \text { mamparamanghon } & \text { say amang as a calling } \\ \text { inang } & \text { mother } & \text { mamparinanghon } & \text { say inang as a calling } \\ \text { roha } & \text { heart } & \text { mamparrohahon } & \text { pay attention } \\ \text { gait } & \text { joke } & \text { mampargaithon } & \text { say something as a joke }\end{array}$

The words can be seen in the following examples:

12. Unang olo hita mamparmeam-meamhon holong ni jolma tu hita.
Don't will us play game
love of person.

'Don't play game on someone's love to us.'

13. Leas do roha na mamparinanghon pangittubu na.

Look down PARTICLE heart him say inang as a calling mother his.

'He looks down to say inang as a calling to his mother.'

The formation of meam-meam as a noun -> mamparmeam-meamhon as a verb includes the combination of prefix mampar- and suffix -hon. Mampar- is the combination of prefixes ma- and par-. Therefore, the verb mamparmeam-meamhon derives from prefix ma- + prefix par- + meam-meam + suffix - hon. Furthermore, mamparmeam-meamhon can be cut into three verbal words, they are (1) mamparmeammeam 'play game', (2) parmeam-meamhon 'play game', and (3) meam-meamhon 'play game'

However, not all words in mampar-base-hon category can be treated as that of the word mamparmeam-meamhon. For instance, the word mamparinanghon derives from parinanghon. In Toba Batak language the words mamparinang and inanghon as derived from mamparinanghon are not found.

\subsection{Denominal Verbs Using tar-Base Category}

In Toba Batak language, the formation of this verb is done by attaching prefix tar- to the nominal base. This kind of verb is not productive in Toba Batak language. Functionally, this prefix forms the base into state verb rather than action verb. Generally the meaning expressed by this state verb is negative meaning because it happens unpurposely as in the following. 


\begin{tabular}{|c|c|c|c|}
\hline Nominal Base & Gloss & Verb Form & Gloss \\
\hline ngingi & tooth & tarngingi & got stuck on the tooth and injured \\
\hline tobbom & bumper & tartobbom & bumped by (a car) unpurposely \\
\hline holi & bone & tarholi & $\begin{array}{l}\text { injured in the throat because of } \\
\text { inhaling the bone of fish or the } \\
\text { bone of meat when eating }\end{array}$ \\
\hline ruoang & hole & tariubang & $\begin{array}{l}\text { step on or ride or drive into the } \\
\text { bigger hole on the street }\end{array}$ \\
\hline
\end{tabular}

Verb formation from nominal bases using tar-base category can be seen in the following sentences.

14. Alani gemor na gabe tarholi ibana mangakkon ikkan mas nabodari. Because greedy him becomes injured by bone him eat gold fish lastnight. 'Because he is greedy he was injured in the throat when he was eating the gold fish last night.'

The word tarholi in the sentence above derives from holi. The change of the lexeme HOLI -> tarholi is derivational because it changes lexeme HOLI as a noun to tarholi as a verb. The same case also occur to ngingi -> tarngingi, tobbom -> tartobbom, and lubang -> tarlubang. The new word forms are intransitive state verbs.

\subsection{Denominal Verbs Using tar-Base-i Category}

Verbs of this category belong to transitive verbs. In this category, prefix tar-and suffix $-i$ are simultaneously attached to the nominal base to form new meaning. Actually, the verb that consists of these affixes - prefix and suffix, at the same time can be divided into two parts. However, only one of the divisions that have meaning in Toba Batak language that is base- $i$ form. For instance, the form tardalani derives from prefix tar- and lexeme DALANI, not lexeme TARDALAN and suffix $-i$. The other examples can be seen in the following:

$\begin{array}{llll}\text { Nominal Base } & \text { Gloss } & \text { Verb Form } & \text { Gloss } \\ \text { dalan } & \text { road } & \text { tardalani } & \begin{array}{l}\text { can be walked, unpurposely walk } \\ \text { on the slippery road }\end{array} \\ \text { takkar } & \text { mug } & \text { tartakkari } & \text { move someting (e.g. rice) }\end{array}$




$\begin{array}{llcl}\text { seddok } & \text { spoon } & \text { tarseddoki } & \begin{array}{c}\text { repeatedly using mug } \\ \text { move someting (e.g. rice) repeatedly } \\ \text { using spoon }\end{array} \\ \text { kareta } \quad \text { (1) motor cycle can be ridden } & \text { (e.g. through certain slippery } \\ \text { path) } & \text { (2) motor cycle can be used (e.g. to } \\ & \text { bring something repeatedly or } \\ \text { to give people a ride) repeatedly }\end{array}$

Verb formation from nominal bases using tar-base- $i$ category can be seen in the following sentence.

15. Dang tardalani dalan on alana marlumpurhian.

Not can be walked road this because muddy very.

'We cannot go through this road because it is very muddy.'

\subsection{Denominal Verbs Using hona-Base Category}

Literally hona means 'suffer from', therefore, in Toba Batak language, hona is a lexical word. Verbs of this category which have negative meanings are not very productive in Toba Batak language. The examples are presented as follows.

$\begin{array}{llll}\text { Nominal base } & \text { Gloss } & \text { Verb Form } & \text { Gloss } \\ \text { panah } & \text { sword } & \text { hona panah } & \text { injured by a sword } \\ \text { bodil } & \text { gun } & \text { hona bodil } & \text { injured by a gun } \\ \text { piso } & \text { knife } & \text { hona pisau } & \text { injured by a knife } \\ \text { pakku } & \text { nails } & \text { hona pakku } & \text { injured by a nail } \\ \text { rassun } & \text { poison } & \text { hona rassun } & \text { being sick or dead because } \\ & & & \text { unpurposely consumes food or } \\ & & & \text { drink contains poison }\end{array}$

\subsection{Denominal Verbs Using marsi-Base-an Category}


Viewed from nominal base, words that belong to this category are intransitive and refer to tools or instruments. However, after prefix marsi- and suffix $-a n$ are attached to the nominal base, the word has negative meaning as shown in the following.

$\begin{array}{llll}\text { Nominal Base } & \text { Gloss } & \text { Verb Form } & \text { Gloss } \\ \text { piso } & \text { knife } & \text { marsipisoan } & \text { hurt one an other using knife } \\ \text { panah } & \text { sword } & \text { marsipanahan } & \text { throwing sword to one an other } \\ \text { aek } & \text { water } & \text { marsiaekan } & \text { pouring water to one an other }\end{array}$

The word marsipisoan, for instance, derives from prefix marsi- + piso + suffix an. If the nominal base is only attached by prefix marsi it will be marsipiso 'looking for knife'. On the other hand, if the word is only attached by suffix -an it will be pisoan and the word pisoan does not have meaning in Toba Batak language. The same things occur to marsipanahan and marsibalatian as well.

\section{CONCLUSIONS}

Based on the discussions on denominal verbs in Toba Batak language above some conlusions can be drawn as in the following.

1. The process occur in forming verbs from nominal bases are derivational process because the word formation changes word class from noun to verbs.

2. Denominal verbs in Toba Batak language can be divided into nine categories, they are: (1) base-zero category, (2) base-hon category, (3) base-i category, (4) mar-base category, (5) mampar-base-hon category, (6) tar-base category, (7) tar-base-i category, (8) hona-base category, and (9) marsi-base-an category.

3. For category (8) hona-base category, "hona" which means "suffer from" is a lexical form attached to bases to form new word as verbs. This category is very different from others in which other categories use affixes instead of lexical form.

4. In Toba Batak language the form of the nominal base and the form of the verb produced is the same in base-zero category. Therefore, the word class of the word will be known as noun or verb from sentence valency. 
5. The new word formed can be transitive or it can be intransitive depends on the affixes attached.

\section{REFERENCES}

Aronoff, Mark. 1976. Word Formation in Generative Grammar. Cambridge: The MIT Press.

Bauer, Laurie. 1983. English Word Formation. Cambridge: Cambridge University Press.

Chaer, Abdul. 2007. Linguistik Umum. Jakarta: Rineka Cipta.

Fromkin, V. R. Rodman and N. Hyams. 2007. An Introduction to Language. Bolton: Thomson, Wadsowooth.

Halle, Morris. 1973. Prolegomena to a Theory of Word Formation. Linguistic Inquiry

Volume IV Number I, 3-16 Winter, 4(I) I/73 (1-108) ISSN 0024-3892.

Katamba, Francis. 1994. Morphology. London: The Macmillan Press.

Lyons, John. 1968. Introduction to Theoretical Linguistics. Cambridge: Cambridge University Press.

Marchand. 1969. The Categories of Types of Present-Day English Word Formation, A Synchronic-diachronic Approaches. (2nd Edition). Munchen: Beck.

Matthes, P. H. 1974. Morphology: An Introduction to the Theory of Word-Structure. Cambridge: Cambridge University Press.

Nida, Eugene A. 1949. Morphology: A Descriptive Analysis of Word. (Second Edition). Ann Arbor: The University of Michigan Press.

Spencer, Andrew. 1992. Morphological Theory: An Introduction to Word Structure in Generative Grammar. Oxford: Blackwell Publishers.

Stump, Gregory T. 2001. Inflectional Morphology: A Theory of Paradigm Structure. Cambridge: Cambridge University Press.

Subroto, D. Edi. 1985. Transposisi dari Adjektiva Menjadi Verba dan Sebaliknya dalam Bahasa Jawa. Disertasi. Jakarta: Universitas Indonesia.

Subroto, D. Edi. 1987. Derivasi dan Infleksi: Kemungkinan Penerapannya dalam Morphology Bahasa Indonesia. Linguistik Indonesia, halaman 51-61.

Verhaar, J.W.M. 1996. Asas-asas Linguistik Umum. Yogyakarta: Gadjah Mada University Press. 
